\title{
CADASTRAL FIELD WORKS ON PREHISTORIC MOUNDS IN THE CENTRAL PART OF THE TISZÁNTÚL REGION
}

\author{
ÁDÁM BEDE \\ University of Szeged, Department of Geology and Palaeontology \\ 2-6., Egyetem Street H-6722 Szeged, Hungary \\ bedeadam@gmail.com
}

\begin{abstract}
The aim of the present paper is to provide a comprehensive report on the cadastral works of mounds in the central part of Tiszántúl (the region east of the Tisza River), taking the burial mounds of the Late Copper Age Yamnaya entity as a starting point. Theoretical and field research began around the beginning of the $19^{\text {th }}$ century, and in the second half of the $20^{\text {th }}$ century systematic site registration took place, mainly due to the so-called 'Archaeological Sites of Hungary' project. Later on national surveys and local initiatives were carried out, but they are of very different quality. In addition to the main characteristics and results of the creation of these cadastres, we also outline further scientific studies on mounds.

Keywords: burial mounds (kurgans), Late Copper Age, Yamnaya entity, cadastral field works, Tiszántúl region
\end{abstract}

\section{INTRODUCTION}

Mounds are not only salient, determining cultural elements of the landscape of the Great Hungarian Plain, but are also of outstanding geological and conservational significance. Through their detailed, multifaceted examination we can study not only the history of millennia, the everyday lives of the people and communities, their archaeological heritage and customs buried in them, but also the inhabited environment, the flora and fauna that once lived there, and the geological formations on the surface and underneath. ${ }^{1}$ Their names and the stories associated with them reveal a hundreds of years' long history. ${ }^{2}$

In the Carpathian Basin, primarily in the Great Hungarian Plain, and especially in the region east of the Tisza River, from the Late Copper Age to the Early Bronze Age, the Yamnaya entity of Eastern European origin also called the People of the Pit Grave Kurgans - played a decisive role. ${ }^{3}$ Their heritage are the thousands of mounds that still exist today. Other cultures that also built and used mounds in the Great Hungarian Plain and in the Tiszántúl region during prehistory and the Migration Period (Scythians, Sarmatians, Hungarians, Cumans, etc.) are not covered in our paper. The reason for this is that, compared to the Yamnaya culture, their barrows are relatively small in number, and for some ethnic groups it is highly questionable if they practiced mound building in the Carpathian Basin at all, despite the fact that there had been strong tendencies in this regard in all of them in Eastern Europe. ${ }^{4}$

\footnotetext{
${ }^{1}$ Bede 2008, 5-9; Pető-BarcZi 2011; Dani-Horváth 2012; BARCZI 2016; BEDE 2016; RÁKÓCZI 2016; DEÁK 2018.

${ }^{2}$ Torma 2008; ToRma 2015, 71-72; Bede 2016, 56-74.
}

\footnotetext{
${ }^{3}$ ECSEDY 1979; DANI-HORVÁTH 2012.

${ }^{4}$ PÁlÓCZI HoRVÁth 1996, 18, 30; KulCSÁr 1998, 40-46.
} 
Our research area is the same as that of the Körös-Maros National Park (Fig. 1) which - with the exception of the Partium region - covers roughly the middle part of the Tiszántúl region. Since the official boundaries of a public institution define our study area, it is unfortunately necessary, at least in part, to have artificial or political boundaries. The borders are roughly: the Tisza in the west; in the south the current state border delineated by the Bánság-sarok (Banat Corner), the Maros River and the Csanádi-hát area (Csanád Ridge); in the east the current state border; in the north the midline of the Kis-Sárrét (Little Sárrét) and Nagy-Sárrét (Great Sárrét) (which is also the administrative boundary of Békés County) and the Körös floodplain. ${ }^{5}$

In this paper, the Great Plain refers to the Great Hungarian Plain defined as a geographical concept with only natural (and not political) borders. An integral part of this is the Bánság (Banat of the Temes/Timiş and Torontál), which is the actual southern Tiszántúl. There is a tendency in the current interpretation of this landscape and common thinking to forget that Bánság (Banat) is part of Tiszántúl and tries to force the landscape concept of Tiszántúl within the modern borders determined in the Trianon Treaty. In contrast, Tiszántúl as a geographical term (geographical name) has been used since the Middle Ages - from the $16^{\text {th }}$ century onwards - and traditional geographical descriptions thinking within the framework of the Carpathian Basin as a geographical unit have all interpreted this area this way. ${ }^{6}$

\section{CADASTRAL WORKS AND THEIR RESULTS}

In the past two hundred years so much diverse and multifaceted research has affected the mounds of our research area that it is impossible to present all; here we are trying to outline concrete mound investigations as the direct antecedents of our own survey. For each of the regions we have already described in detail the archaeological surveys and the research on landscape and environmental history, first is in the vicinity of Szentes and then in other parts of the study area as well. ${ }^{7}$

Already the very first, $19^{\text {th }}$-century local works emphasized the importance of collecting and organizing the mounds, and geographers were looking for the regularities in their location. ${ }^{8}$ In the 1850 s and 1860 s, the geologist József Szabó studied the structure of the mounds of Békés and Csanád Counties in addition to other regions. ${ }^{9}$ The local history literature of the $19^{\text {th }}$ century also often mentions the mounds, usually highlighting their local aspects, but with little recognition of their wider connections and the relationship between the individual regions at that time.

Systematic research started only from the first half of the $20^{\text {th }}$ century. In his writing Béla Kozma examines the distribution and geomorphological characteristics of the mounds through the eye of a geographer. His map appendix, which was edited on the basis of a later, lower resolution version of the Third Military Survey, depicts the entire Great Plain, including the entire Tiszántúl region; it depicts 127 mounds in our study area (Fig. 2). ${ }^{10}$

In our area, the first work specifically designed to register mounds is connected to the name of Gyula Szeghalmi (Fig. 3), who collected the mounds of Nagy-Sárrét area belonging to the Szeghalom District in Békés County, a total of $60 .{ }^{11}$

József Csalog, as director of the Koszta József Museum, surveyed the most important mounds in the wider area of Szentes. He examined their condition, environment, relationship to each other and to other sites, and collected scattered finds from their surface. He made a repository report (field log) of the surveyed mounds and the finds found during each survey. He also mentions a map he himself made, showing the results of the mound registration efforts in the vicinity of Szentes; however, we have not been able to find it so far. He made useful observations about the geographic location of the mounds, their relief and hydrological context, and other related phenomena observable in the field, such as rings surrounding the mounds. ${ }^{12}$ It is fortunate to have his field observa-

\footnotetext{
${ }^{5}$ DöVÉNYI 2010; DEÁK 2010; JAKAB-Deli 2012, 26-27.

${ }^{6}$ KISS 1988, II. 653; KÁDÁR 1941.

${ }^{7}$ Bede 2008, 10-17; BEDE 2016, 17-25.

${ }^{8}$ Perecsenyi Nagy 1819, 80; Nagy 1819, 37.
}

\footnotetext{
${ }^{9}$ SZABÓ 1859.

${ }^{10}$ Kozma 1910, Pl. XXVII.

${ }^{11}$ Szeghalmi 1912; Szeghalmi 1936.

${ }^{12}$ Csalog $1954,82$.
} 


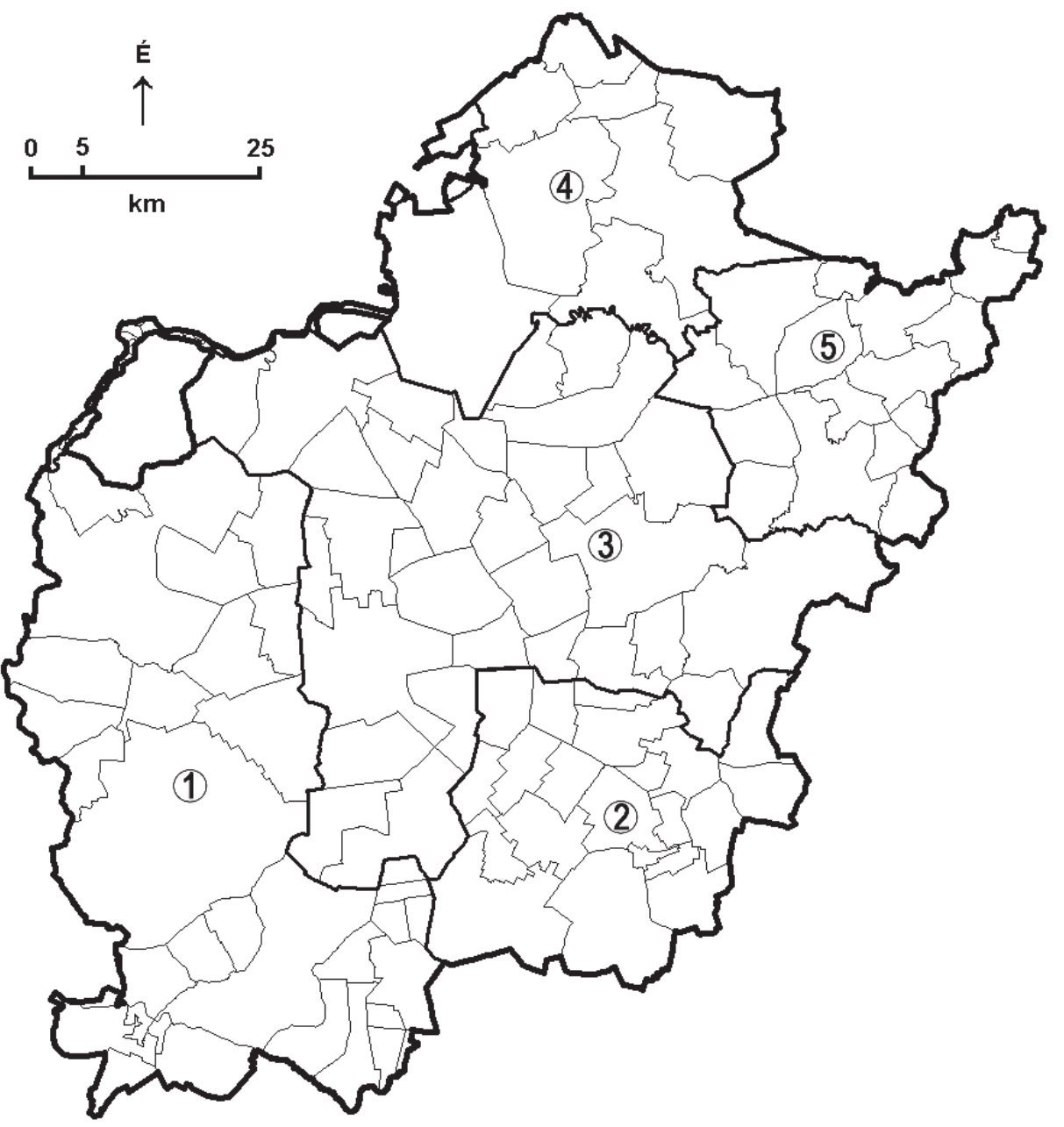

Fig. 1. The study area with the border lines of settlements and surveyed land units.

1: Eastern part of Csongrád County; 2: Csanádi-hát area; 3: Békési-hát area; 4: Nagy-Sárrét area; 5: Kis-Sárrét area

tions made in the first half of the 1950s, preceding the spread of deep ploughing and heavy-duty machines, so he could see the mounds in a more original and intact state. ${ }^{13}$

In Békés County, the first mound registration works were launched within the framework of the 'Magyarország Régészeti Topográfiája' ( = MRT, ‘Archaeological Sites of Hungary’) research program. The MRT staff set the goal of gathering, in the long term, all the sites that could still be detected and identified by field walking. This is how the research started in the northern and central parts of Békés County, which were jointly carried out by the experts of the Institute of Archaeology of the Hungarian Academy of Sciences and the Békés County Museum Directorate. The work started in 1969 and is practically still in progress. ${ }^{14}$ The results of the decades-long effort are three published volumes ${ }^{15}$ and one more in preparation. ${ }^{16}$ In addition to the sites of other periods, the mounds were also collected as comprehensively as possible, adding accurate, reliable data and status descriptions to the cadastre (Fig. 4; Table 1). A total of 644 kurgans were registered during the surveys.

The next cadastre was created by Dénes Virágh for István Ecsedy's book discussing the kurgans of the Tiszántúl region; he collected 909 mounds from our study area. ${ }^{17}$ His work relies almost entirely on the results of the MRT, but he also conducted independent research, mainly on the basis of the First and Second Military Surveys,

${ }^{13}$ BEDE 2008, 14

${ }^{14}$ BAKAY 1971.

${ }^{15}$ MRT 6; MRT 8; MRT 10.

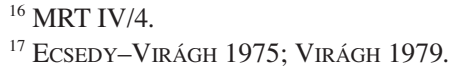

${ }^{17}$ ECSEDY-VIRÁGH 1975; VIRÁGH 1979. 


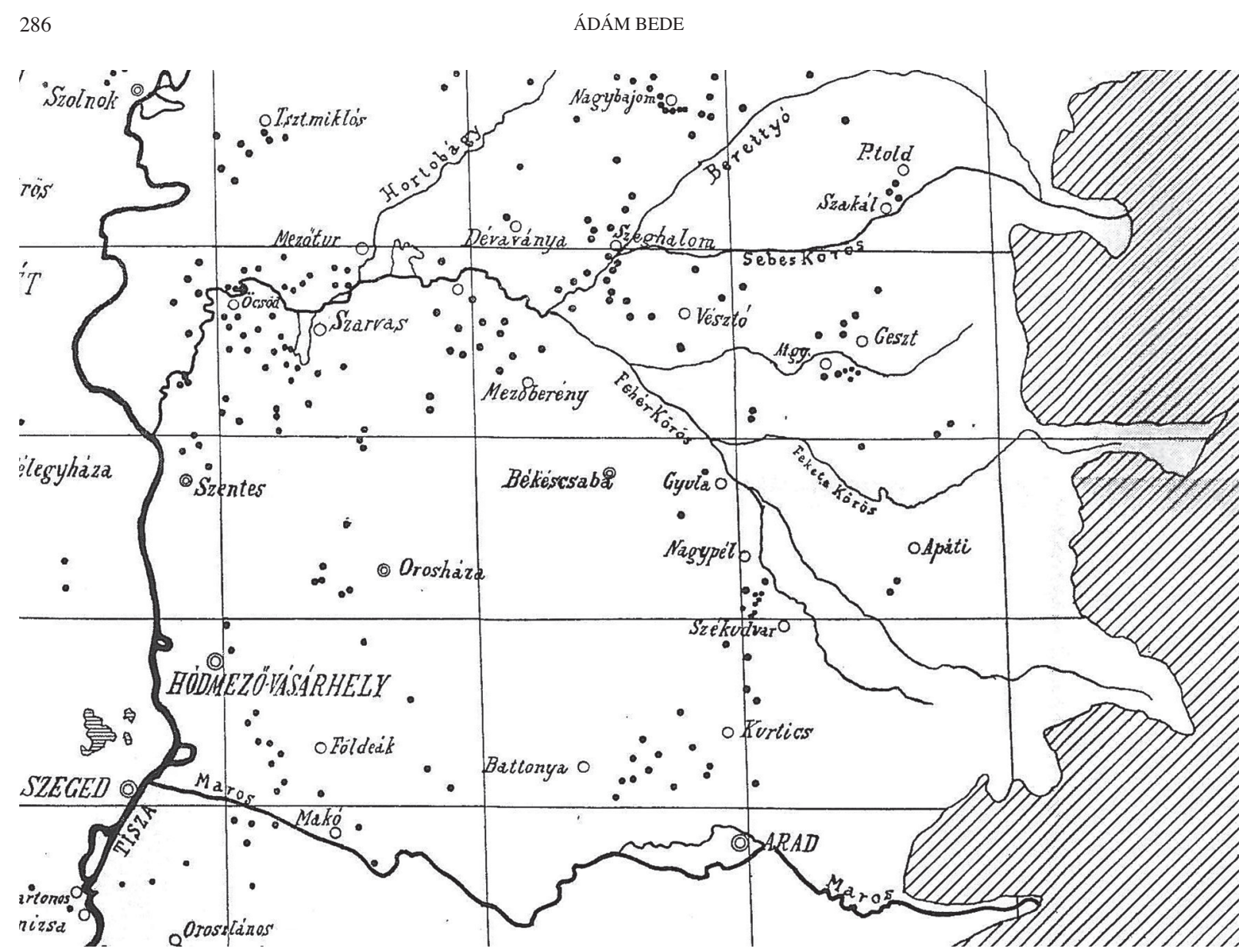

Fig. 2. Béla Kozma's map with kurgans in the study area (KozmA 1910, Pl. XXVII)

but without field surveys and identification (Fig. 5; Table 1). The cadastre is a laconic list, never including the exact location, and only marks the mounds on a large-scale sketch map. Since Virágh did not check the data obtained from the maps in the field, there were a relatively large number of elevated points that are not anthropogenic mounds but natural geological formations.

In 1979, with the help of the interwar version of the Third Military Survey, on-site inspections, and even test coring, Gábor Rózsa prepared a mound cadastre for Csongrád County, which contained a total of 118 mounds in our test area. ${ }^{18}$ The most significant mounds appear - on a sketch map - with their best-known names (Fig. 6; Table 1). Rózsa also copied the mound descriptions of the Béla Bodnár's toponym collection for geographic purpose $^{19}$ and provided them with comments. In many cases he arbitrarily and erroneously criticized Bodnár's more thorough and accurate work. ${ }^{20}$

Later on László Szelekovszky sketched a brief review of the mounds of Békés County. He listed 558 in his cadastre. Most of this list was compiled from the MRT volumes, but - mainly in the central and southern parts of the county - he also carried out independent research. ${ }^{21}$ However, his work is superficial and abridged; the list does not contain coordinates, and the map appendices are difficult to interpret (Fig. 7).

In 2001, the Institute of Archaeology of the Eötvös Loránd University also compiled a list of mounds ${ }^{22}$ for which the data from the MRT and Dénes Virágh's work were copied - most often erroneously. This work is virtually unusable due to the inaccuracy of the coordinates; furthermore, no field surveys were made. There are 159 mounds in the list from our area, whose coordinates are more or less real (accurate within $100 \mathrm{~m}$ ).

\footnotetext{
${ }^{18}$ Rózsa 1979.

${ }^{19}$ BODNÁR 1983.

${ }^{20}$ RÓZSA 2002.
}

${ }^{21}$ SZELEKOVSZKY 1999.
${ }^{22}$ ELTE 2001.

Acta Archaeologica Academiae Scientiarum Hungaricae 70, 2019 


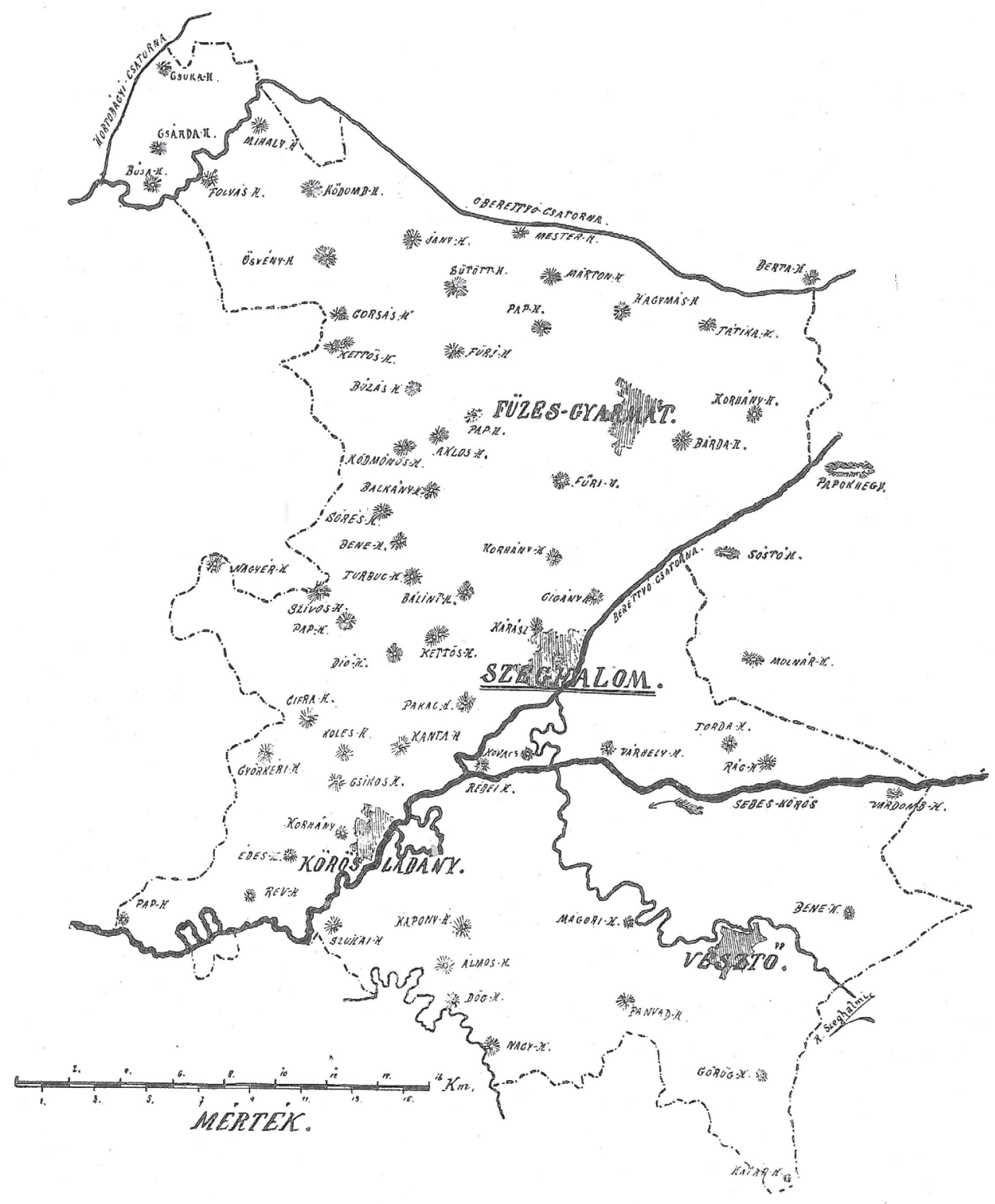

Fig. 3. Gyula Szeghalmi's map with the kurgans in the vicinity of Szeghalom (SzEGHALMI 1912, 279)

Another cadastre was completed in 2002, within the framework of the so-called 'Kunhalom-program', under the co-ordination of the Alföldkutatásért Alapitvány (Foundation for the Study of the Great Hungarian Plain) from Kisújszállás. Its aim was to collect all (or mainly the still existing) mounds in the entire territory of the country. ${ }^{23}$ This cadastre is more detailed, multifaceted and accurate than the previous three, but it contains much less mounds: 474 in our study area (Fig. 8; Table 1). Another disadvantage of the survey is that the database contains a large number of natural elevations that are not anthropogenic mounds. Despite the problems outlined, the 'National Kunhalom Cadastre and Database', implemented within the framework of the 'Kunhalom-program', was a huge step forward in the survey work, as no such co-operation and organization (apart from one or two local initiatives) took place before. However, we have to see that the results obtained are not sufficient, especially in the case of the lowest, non-significant mounds, so filling in the gaps and adding the missing mounds to the database is absolutely necessary in the future.

${ }^{23}$ Kunhalom-program 2002; То́тн-То́тн 2011. 
Table 1.

Cadastral works on mounds in the study area

\begin{tabular}{|c|c|c|c|c|c|}
\hline Settlement & \begin{tabular}{|l|} 
MRT \\
$6,8,10$, IV/4
\end{tabular} & VIRÁGH 1979 & RózSA 1979 & $\begin{array}{l}\text { Kunhalom-program } \\
2002\end{array}$ & BEDE 2016 \\
\hline Almáskamarás & - & 0 & - & 0 & 4 \\
\hline Ambrózfalva & - & 0 & 0 & 0 & 0 \\
\hline Apátfalva & - & 3 & 0 & 0 & 5 \\
\hline Árpádhalom & - & 5 & 0 & 2 & 17 \\
\hline Battonya & - & 15 & - & 12 & 42 \\
\hline Békés & 25 & 12 & - & 6 & 59 \\
\hline Békéscsaba & 8 & 2 & - & 2 & 18 \\
\hline Békéssámson & - & 3 & - & 0 & 9 \\
\hline Békésszentandrás & 17 & 15 & - & 8 & 26 \\
\hline Bélmegyer & 10 & 8 & - & 7 & 31 \\
\hline Biharugra & 41 & 41 & - & 35 & 51 \\
\hline Bucsa & 4 & 4 & - & 0 & 7 \\
\hline Csabacsüd & 3 & 3 & - & 1 & 3 \\
\hline Csabaszabadi & 0 & 3 & - & 0 & 4 \\
\hline Csanádalberti & - & 1 & 1 & 1 & 4 \\
\hline Csanádapáca & - & 0 & - & 1 & 10 \\
\hline Csanádpalota & - & 2 & 0 & 3 & 12 \\
\hline Csárdaszállás & 11 & 8 & - & 7 & 20 \\
\hline Csorvás & - & 2 & - & 1 & 12 \\
\hline Derekegyház & - & 5 & 4 & 2 & 6 \\
\hline Deszk & - & 5 & 3 & 14 & 25 \\
\hline Dévaványa & 70 & 70 & - & 69 & 114 \\
\hline Doboz & 1 & 3 & - & 0 & 5 \\
\hline Dombegyház & - & 8 & - & 6 & 29 \\
\hline Dombiratos & - & 2 & - & 0 & 4 \\
\hline Ecsegfalva & 6 & 4 & - & 4 & 16 \\
\hline Elek & - & 5 & - & 0 & 12 \\
\hline Eperjes & 1 & 6 & 4 & 5 & 10 \\
\hline Fábiánsebestyén & - & 5 & 6 & 0 & 13 \\
\hline Ferencszállás & - & 1 & 0 & 0 & 4 \\
\hline Földeák & - & 5 & 2 & 2 & 6 \\
\hline Füzesgyarmat & 46 & 46 & - & 40 & 74 \\
\hline Gádoros & - & 0 & - & 0 & 1 \\
\hline Gerendás & - & 0 & - & 0 & 7 \\
\hline Geszt & 30 & 27 & - & 0 & 48 \\
\hline Gyomaendrőd & 65 & 53 & - & 28 & 124 \\
\hline Gyula & 29 & 26 & - & 10 & 64 \\
\hline Hódmezővásárhely & - & 42 & 20 & 20 & 166 \\
\hline Hunya & 0 & 0 & - & 0 & 0 \\
\hline Kamut & 0 & 1 & - & 0 & 1 \\
\hline Kardos & 0 & 0 & - & 0 & 1 \\
\hline Kardoskút & - & 3 & - & 1 & 9 \\
\hline Kaszaper & - & 1 & - & 0 & 1 \\
\hline Kertészsziget & 6 & 6 & - & 4 & 6 \\
\hline Kétegyháza & 6 & 24 & - & 1 & 72 \\
\hline Kétsoprony & 0 & 0 & - & 0 & 1 \\
\hline Kevermes & - & 5 & - & 2 & 18 \\
\hline Királyhegyes & - & 3 & 2 & 1 & 5 \\
\hline Kisdombegyház & - & 2 & - & 0 & 7 \\
\hline Kiszombor & - & 9 & 5 & 2 & 11 \\
\hline Klárafalva & - & 3 & 1 & 3 & 3 \\
\hline
\end{tabular}


Table 1. cont.

\begin{tabular}{|c|c|c|c|c|c|}
\hline Settlement & $\begin{array}{l}\text { MRT } \\
6,8,10, \mathrm{IV} / 4\end{array}$ & VIRÁGH 1979 & RózSA 1979 & $\begin{array}{l}\text { Kunhalom-program } \\
2002\end{array}$ & BEDE 2016 \\
\hline Kondoros & 0 & 3 & - & 0 & 4 \\
\hline Körösladány & 36 & 35 & - & 14 & 63 \\
\hline Körösnagyharsány & 8 & 8 & - & 3 & 10 \\
\hline Köröstarcsa & 12 & 15 & - & 4 & 24 \\
\hline Körösújfalu & 19 & 19 & - & 3 & 31 \\
\hline Kötegyán & 0 & 0 & - & 0 & 0 \\
\hline Kövegy & - & 0 & 0 & 0 & 0 \\
\hline Kunágota & - & 1 & - & 0 & 10 \\
\hline Kunszentmárton & - & 1 & - & 1 & 1 \\
\hline Kübekháza & - & 8 & 1 & 3 & 11 \\
\hline Lőkösháza & - & 1 & - & 0 & 7 \\
\hline Magyarbánhegyes & - & 0 & - & 0 & 0 \\
\hline Magyarcsanád & - & 12 & 1 & 4 & 22 \\
\hline Magyardombegyház & - & 0 & - & 0 & 0 \\
\hline Makó & - & 19 & 10 & 11 & 48 \\
\hline Maroslele & - & 3 & 1 & 2 & 5 \\
\hline Mártély & - & 3 & 3 & 2 & 25 \\
\hline Medgyesbodzás & - & 0 & - & 0 & 7 \\
\hline Medgyesegyháza & - & 5 & - & 3 & 20 \\
\hline Méhkerék & 2 & 1 & - & 0 & 5 \\
\hline Mesterszállás & - & 0 & - & 0 & 0 \\
\hline Mezőberény & 12 & 13 & - & 3 & 40 \\
\hline Mezőgyán & 15 & 10 & - & 0 & 25 \\
\hline Mezőhegyes & - & 2 & 1 & 1 & 5 \\
\hline Mezőkovácsháza & - & 1 & - & 0 & 9 \\
\hline Mezőtúr & - & 1 & - & 0 & 4 \\
\hline Mindszent & - & 8 & 7 & 4 & 9 \\
\hline Murony & 0 & 0 & - & 0 & 0 \\
\hline Nagybánhegyes & - & 0 & - & 0 & 0 \\
\hline Nagyér & - & 0 & 0 & 0 & 1 \\
\hline Nagykamarás & - & 9 & - & 3 & 29 \\
\hline Nagylak & - & 1 & 0 & 0 & 2 \\
\hline Nagymágocs & - & 1 & 0 & 0 & 10 \\
\hline Nagyszénás & - & 5 & - & 3 & 6 \\
\hline Nagytőke & - & 7 & 6 & 4 & 23 \\
\hline Óföldeák & - & 8 & 3 & 2 & 20 \\
\hline Okány & 4 & 3 & - & 0 & 4 \\
\hline Orosháza & - & 2 & - & 0 & 27 \\
\hline Öcsöd & - & 0 & - & 0 & 3 \\
\hline Örménykút & 6 & 5 & - & 5 & 7 \\
\hline Pitvaros & - & 2 & 1 & 1 & 10 \\
\hline Pusztaföldvár & - & 0 & - & 0 & 3 \\
\hline Pusztaottlaka & - & 1 & - & 1 & 11 \\
\hline Sarkad & 0 & 0 & - & 0 & 3 \\
\hline Sarkadkeresztúr & 1 & 0 & - & 7 & 17 \\
\hline Szabadkígyós & 3 & 0 & - & 1 & 16 \\
\hline Szarvas & 24 & 21 & - & 11 & 46 \\
\hline Szeged & - & 0 & 0 & 0 & 0 \\
\hline Szeghalom & 58 & 58 & - & 16 & 108 \\
\hline Szegvár & - & 7 & 7 & 4 & 17 \\
\hline Székkutas & - & 15 & 5 & 4 & 47 \\
\hline Szelevény & - & 0 & - & 0 & 0 \\
\hline
\end{tabular}


Table 1. cont.

\begin{tabular}{|c|c|c|c|c|c|}
\hline Settlement & $\begin{array}{l}\text { MRT } \\
6,8,10, \mathrm{IV} / 4\end{array}$ & VIRÁGH 1979 & RózSA 1979 & $\begin{array}{l}\text { Kunhalom-program } \\
2002\end{array}$ & BEDE 2016 \\
\hline Szentes & 2 & 42 & 24 & 17 & 86 \\
\hline Tarhos & 1 & 0 & - & 0 & 6 \\
\hline Telekgerendás & 0 & 0 & - & 0 & 1 \\
\hline Tiszaföldvár & - & 0 & - & 0 & 0 \\
\hline Tótkomlós & - & 2 & - & 1 & 15 \\
\hline Túrkeve & 8 & 4 & - & 1 & 18 \\
\hline Újkígyós & 5 & 0 & - & 0 & 27 \\
\hline Újszalonta & 0 & 0 & - & 0 & 0 \\
\hline Végegyháza & - & 3 & - & 0 & 6 \\
\hline Vésztő & 28 & 28 & - & 14 & 58 \\
\hline Zsadány & 21 & 19 & - & 21 & 37 \\
\hline total & (644) & 909 & (118) & 474 & 2335 \\
\hline
\end{tabular}

\section{OUR SURVEY AND THE MAIN RESULTS}

Our research was carried out with the commission and support of the Körös-Maros National Park Directorate. Our task was to fully map and survey the state of the mounds in the operation area of the directorate. This work was carried out through interconnected landscapes (Fig. 1): 1. Csongrád County's part in the Tiszántúl region (665 mounds); 2. the Csanádi-hát area (Csanád Ridge) (252 mounds); 3. the Békési-hát area (Békés Ridge) (552 mounds); 4. the Nagy-Sárrét of Békés County (535 mounds); 5. the Kis-Sárrét of Békés County (331 mounds). It covers the administrative area of 114 settlements with a total area of 797,703 ha (or nearly $8000 \mathrm{~km}^{2}$ ); a total of 2335 mounds were mapped (Fig. 9; Table 1). ${ }^{24}$

In addition to $18^{\text {th }}-20^{\text {th }}$-century manuscript and printed maps, we also used archival sources, repository reports, and literature from local history, archaeology, ethnography, onomastics and natural sciences.

The primary objective of the survey of the mounds of the central Tiszántúl region was to search for mounds with natural and landscape value, and those that had been hitherto unknown; thus, we also carried out a survey of their natural state, and geoarchaeological and environmental historical aspects were also kept in mind. We were also curious about the main geomorphological characters, natural conditions and the ecological features and values of the mounds of a well-defined and relatively uniform landscape. This required the complete collection of the mounds of the study area. Furthermore, such a large-scale, representative study with a large number of mounds focusing on multiple details can provide a method and model for future mound research that will allow us to compare the various - often genetically different - landscapes of the Great Hungarian Plain. In order to collect data, in addition to the basic cadastral research and status survey, we also carried out landscape archaeological, environmental historical, geomorphological, archaeological stratigraphic, GIS, botanical and onomastic studies.

\section{OTHER SCIENTIFIC EXAMINATIONS OF THE MOUNDS}

In the central Tiszántúl, not only mound registering and status surveys have been carried out; some researchers also conducted other scientific investigations and for the sake of the review we would like to mention these as well in a paragraph.

The geomorphological and landscape geographical features, anthropogenic effects, microclimate and soil conditions ${ }^{25}$ and later the botanical aspects of the kurgans of Kétegyháza were investigated ${ }^{26}$ and their reconstruction possibilities assessed. ${ }^{27}$

${ }^{24}$ BEDE 2016, 27-55.

${ }^{25}$ DövÉNYI et al. 1977, 48-49, Fig. 1; RAKONCZAI 1986, 10, 16; DöVÉNYI 1986, 83, 94; BARCZI 2016, 102-107.
${ }^{26}$ Kertész 2000; MedovarsZKy 2010.
${ }^{27}$ NAGY 2012; BEDE-CZUKOR 2018. 


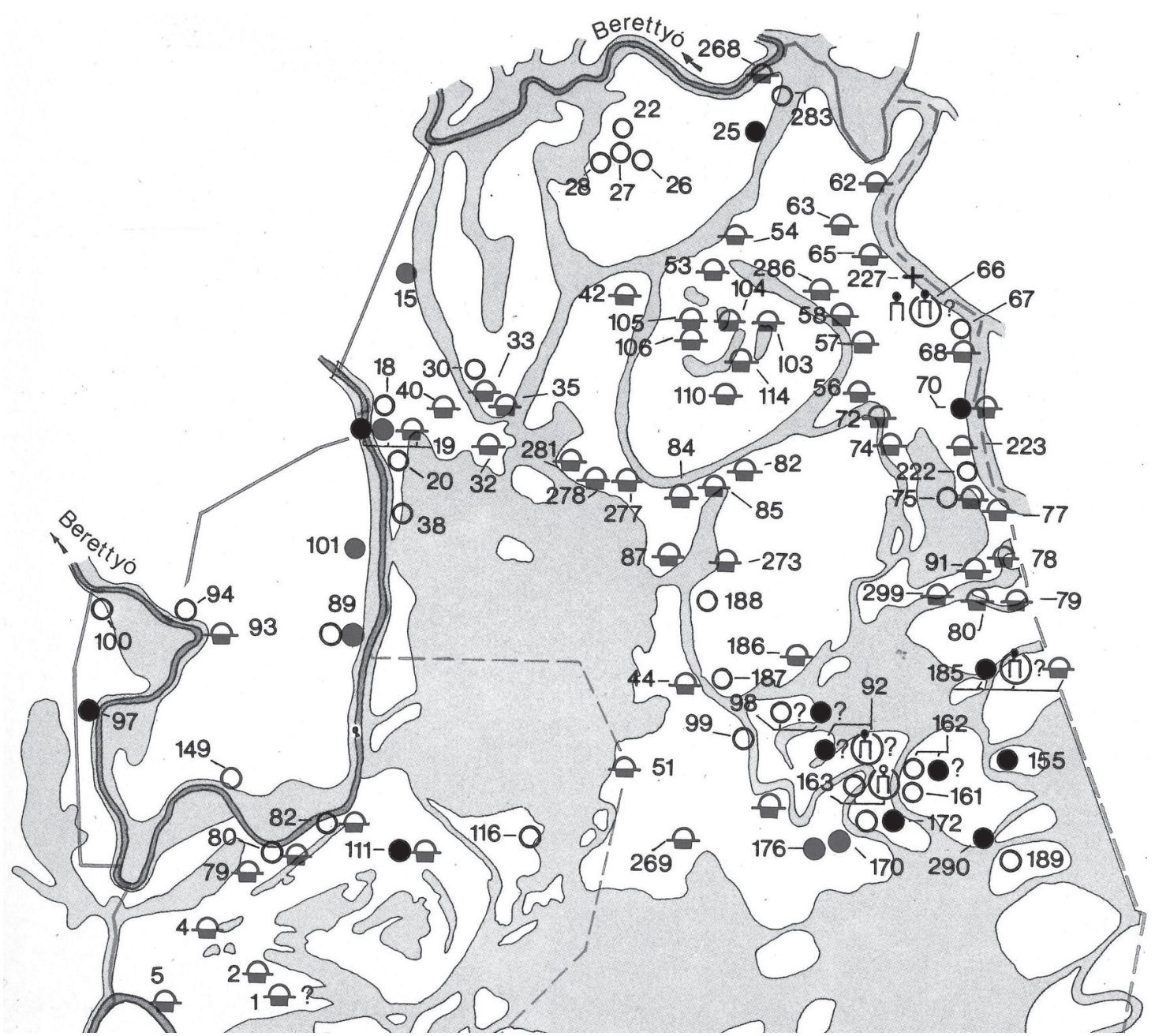

Fig. 4. Kurgans near Gyomaendrőd on the map by Archaeological Sites of Hungary (MRT 8, Annex 2)

Botanists have gathered floristic data from a number of kurgans in the Maros-Körös Interfluve. ${ }^{28}$ They evaluated the vegetation of a few mounds near Szentes, ${ }^{29}$ characterized the weeds and landscape history of the Hegyes-halom near Mindszent, ${ }^{30}$ investigated the soil and the connections between hydrology and vegetation on the Kántor-halom near Szentes, ${ }^{31}$ surveyed the vegetation of the Sáp-halom near Szegvár, ${ }^{32}$ and in addition to the study of vegetation, the effects of farming were also analysed at the Hegyes-halom near Kéthegyháza, the Bekai-halom in Magyarcsanád and the Bőve-halom in Hódmezővásárhely. ${ }^{33}$ Complete flora lists were made on all the mounds of the Csanádi-hát area with permanent vegetation ${ }^{34}$ and the mounds around Szarvas were also surveyed. ${ }^{35}$ fauna. $^{39}$

Zoologists also gathered information about periwinkle insects, ${ }^{36}$ beetles, ${ }^{37}$ molluscs ${ }^{38}$ and vertebrate

${ }^{28}$ KovÁCS-Molnár 1986, 187-192; MolnÁr 1992, 22 23; Kapocsi et al. 1998; PenKSZA-KapoCsi 1998; KertésZ 2000; TótH 2003; JAKAB-TóTH 2003; DEÁK 2018, 78-81.

${ }^{29}$ KISPÁL 2002; 2004.

${ }^{30}$ BEDE 2016, 89.

${ }^{31}$ Barczi 2003; Vona-Penksza 2004; Penksza et al. 2005; HERCZEG et al. 2006b.

${ }^{32}$ Herczeg et al. 2006a.
${ }^{33}$ PenKsZa et al. 2005; HercZeg 2005; HercZeg et al. 2009; BARCZI et al. 2011; HERCZEG 2015, 43-53.

${ }^{34}$ CSATHÓ 2008; BEDE 2016, 86-87.

${ }^{35}$ DÉTÁR 2012.

${ }^{36}$ KRAUSZ et al. 2000.

${ }^{37}$ MerkL et al. 2014.

${ }^{38}$ Dомокоs 2018a; Dомокоs 2018b.

${ }^{39}$ CsizmaZia 1982; CsizmaZia 1986.

Acta Archaeologica Academiae Scientiarum Hungaricae 70, 2019 


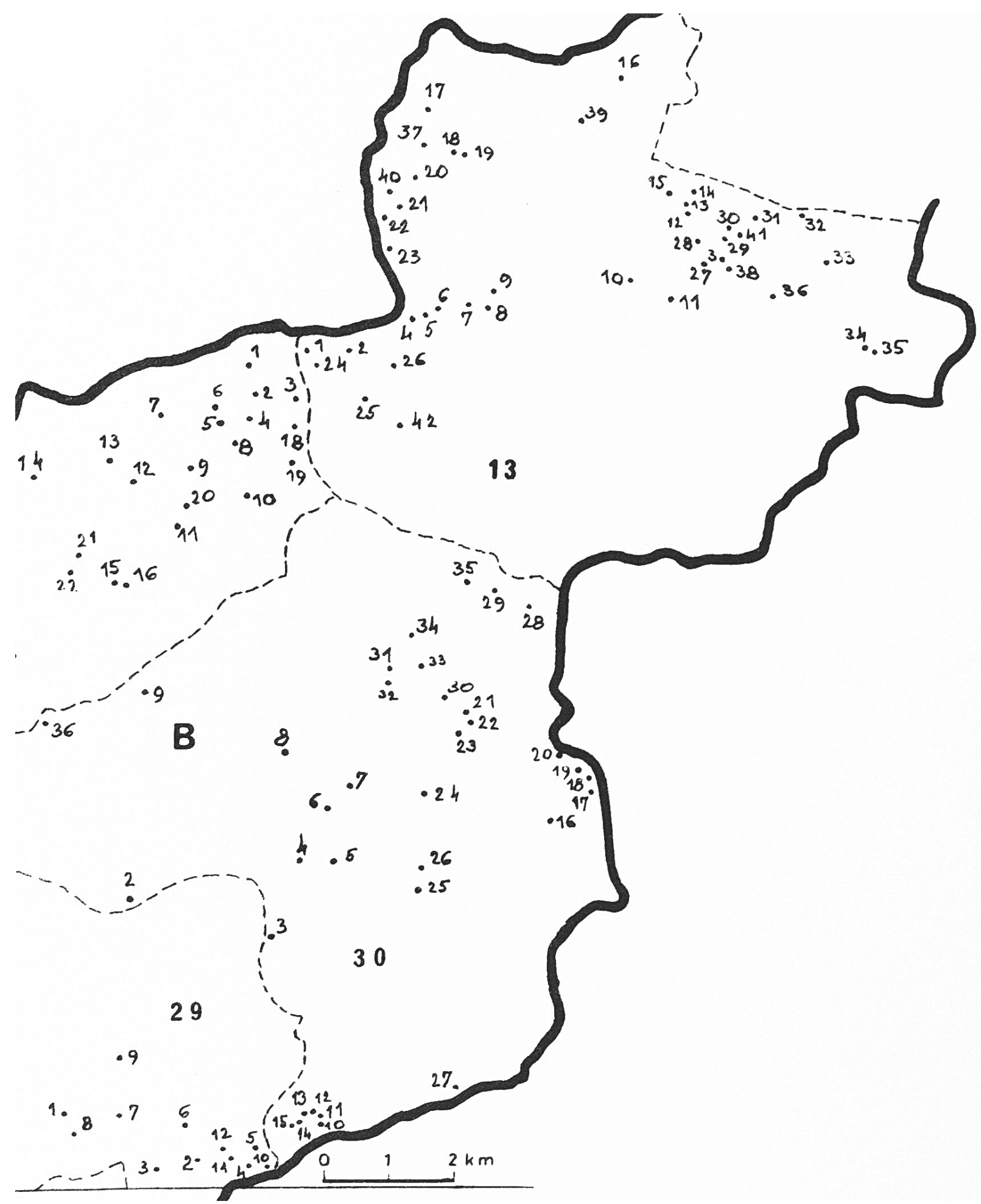

Fig. 5. Dénes Virágh's map with the kurgans in the Kis-Sárrét area (VIRÁGH 1979, Suppl. 4) 


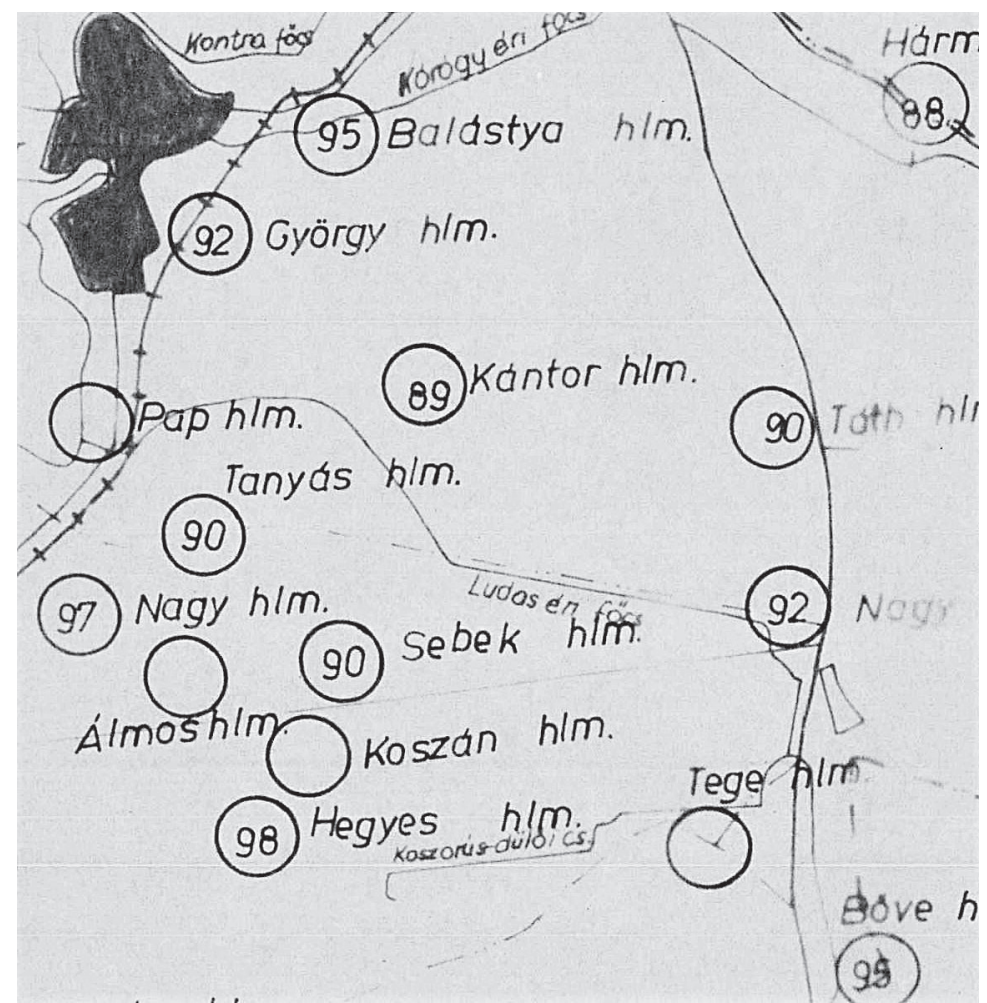

Fig. 6. Cadastre of Csongrád County by Gábor Rózsa with the kurgans near Szegvár (RózSA 1979)

Antónia Marcsik ${ }^{40}$ and Zsuzsanna K. Zoffmann ${ }^{41}$ analysed several human skeletal remains discovered in kurgans in our area. Sándor Bökönyi investigated the vertebrate fauna from Kétegyháza, ${ }^{42}$ while the chemical composition of the ochre pieces from the Tiszántúl region was analysed by György Duma. ${ }^{43}$

Attila Rákóczi analysed the ecological changes on previously cultivated mounds. An important aspect of his research was the mapping of the local communities' relationship with the barrows. ${ }^{44}$

\section{CONCLUSION}

In the study area - the central Tiszántúl region - there has been continuous development both professionally and methodologically and with regard to instrumental analyses in connection with the registration of mounds. The published and unpublished (in preparation) volumes for Békés County of the 'Archaeological Sites of Hungary' (MRT) series provide a milestone in this research. Already the authors of the topographic volumes had recognized the need to analyse manuscript maps and archival documents, and due to the use of these sources, fundamental observations were made regarding the number, location and condition of the mounds. Some of the subsequent cadastral works also used this elaborate working method in their own surveys.

In the future it is absolutely necessary to include other sample areas in the Great Plain (especially east of the Tisza) with similar sample numbers and sizes, so that the properties of the mounds of each region can be compared. It is important that surveys and evaluations should be consistent on their own, but they should also be comparable to the results of other surveyed areas. We are thinking here primarily of the use of the sources, the protocol of field observations and site surveys, and the need to strive for completeness. We are confident that these regional researches on mounds will start in the near future in other parts of the Carpathian Basin as well in increasing numbers.

\footnotetext{
${ }^{40}$ MARCSIK 1979.

${ }^{41}$ K. ZoFFMANN 1978; K. ZoFFMANn 1984.

${ }^{42}$ BÖKÖNYI 1979.
}

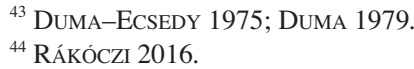




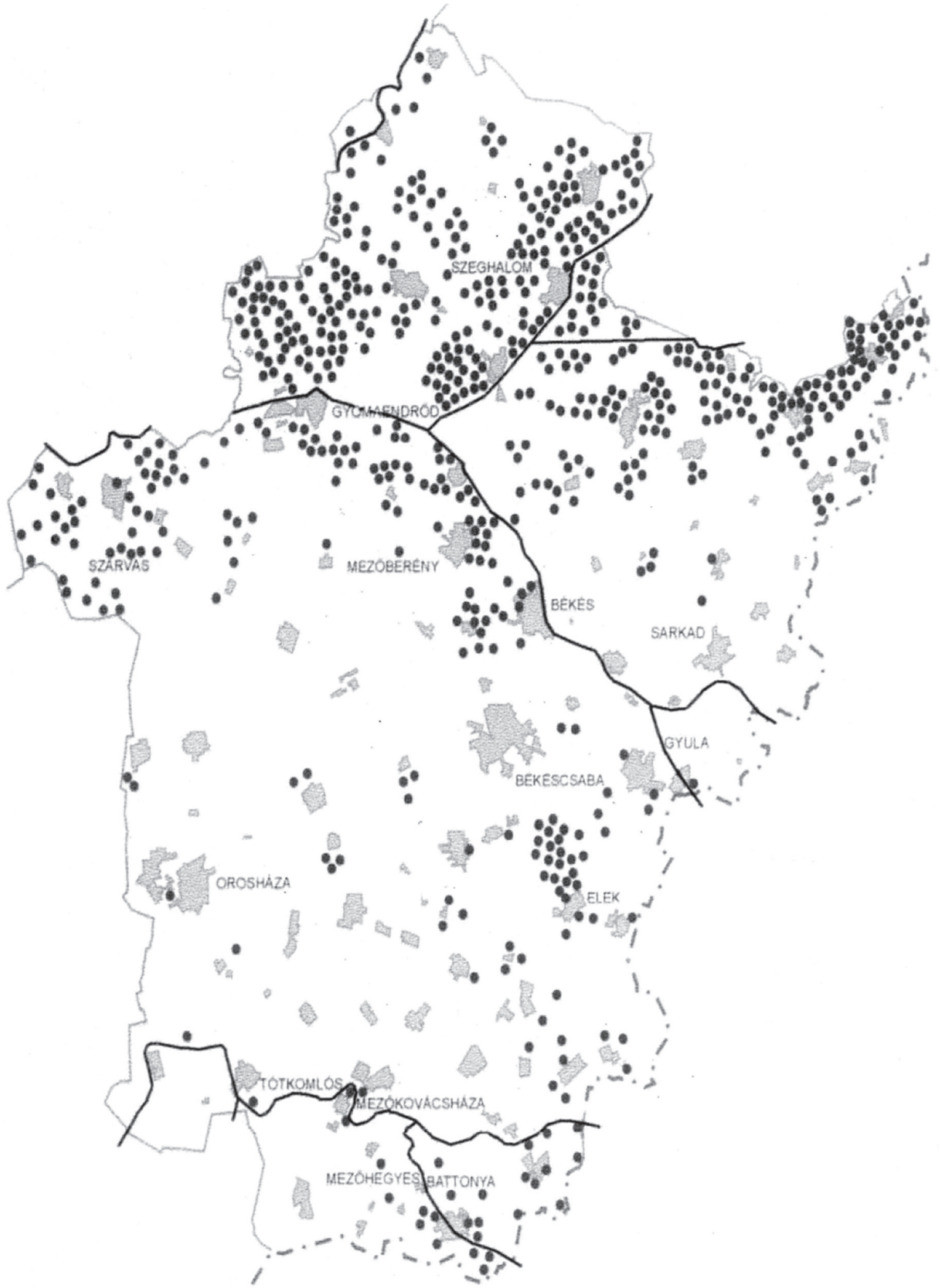

Fig. 7. László Szelekovszky's map with the mounds of Békés County (SzELEKovszKy 1999, 3) 


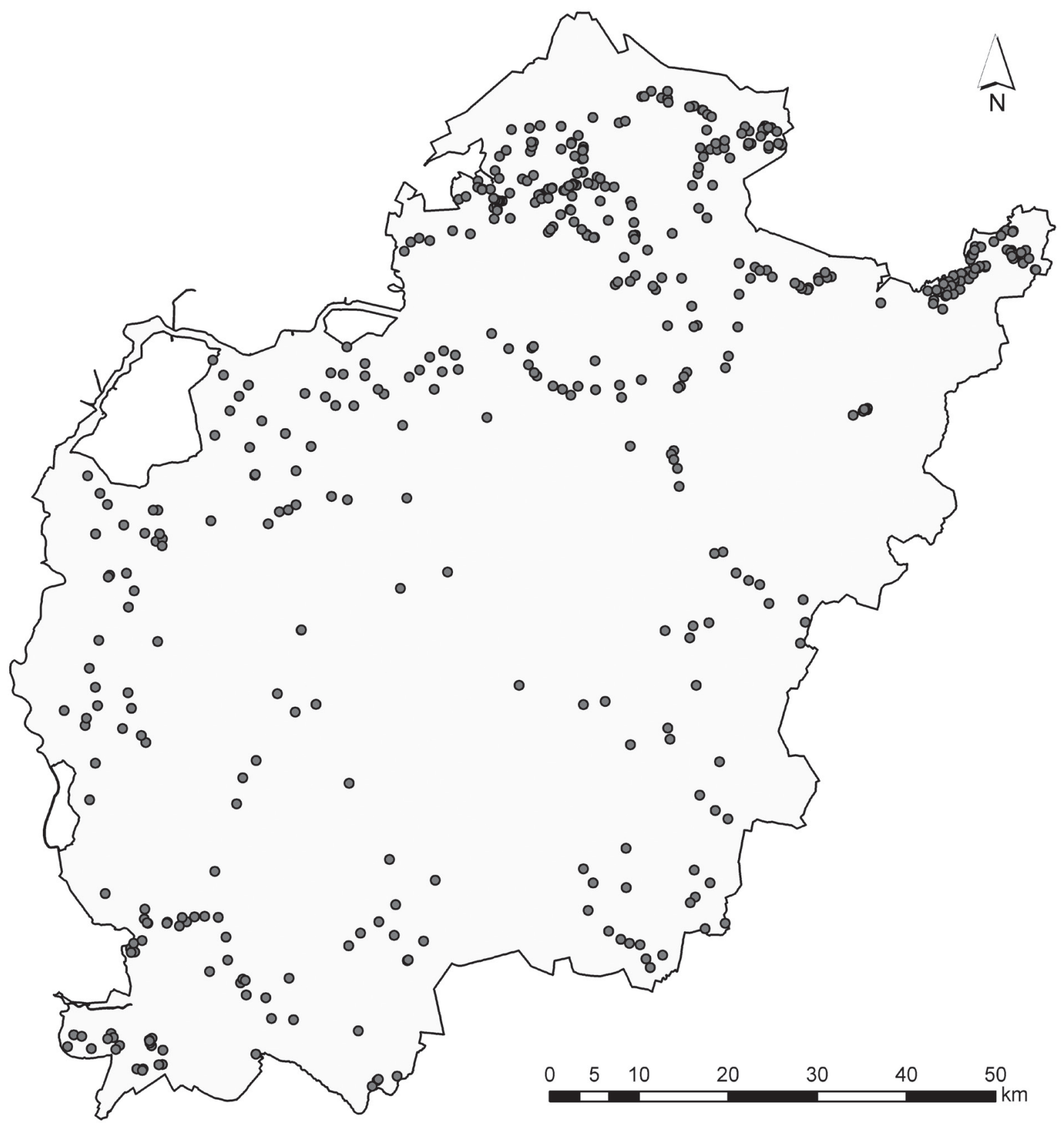

Fig. 8. The assessed kurgans by the 'Kunhalom project' in the study area (based on Kunhalom-program 2002) 


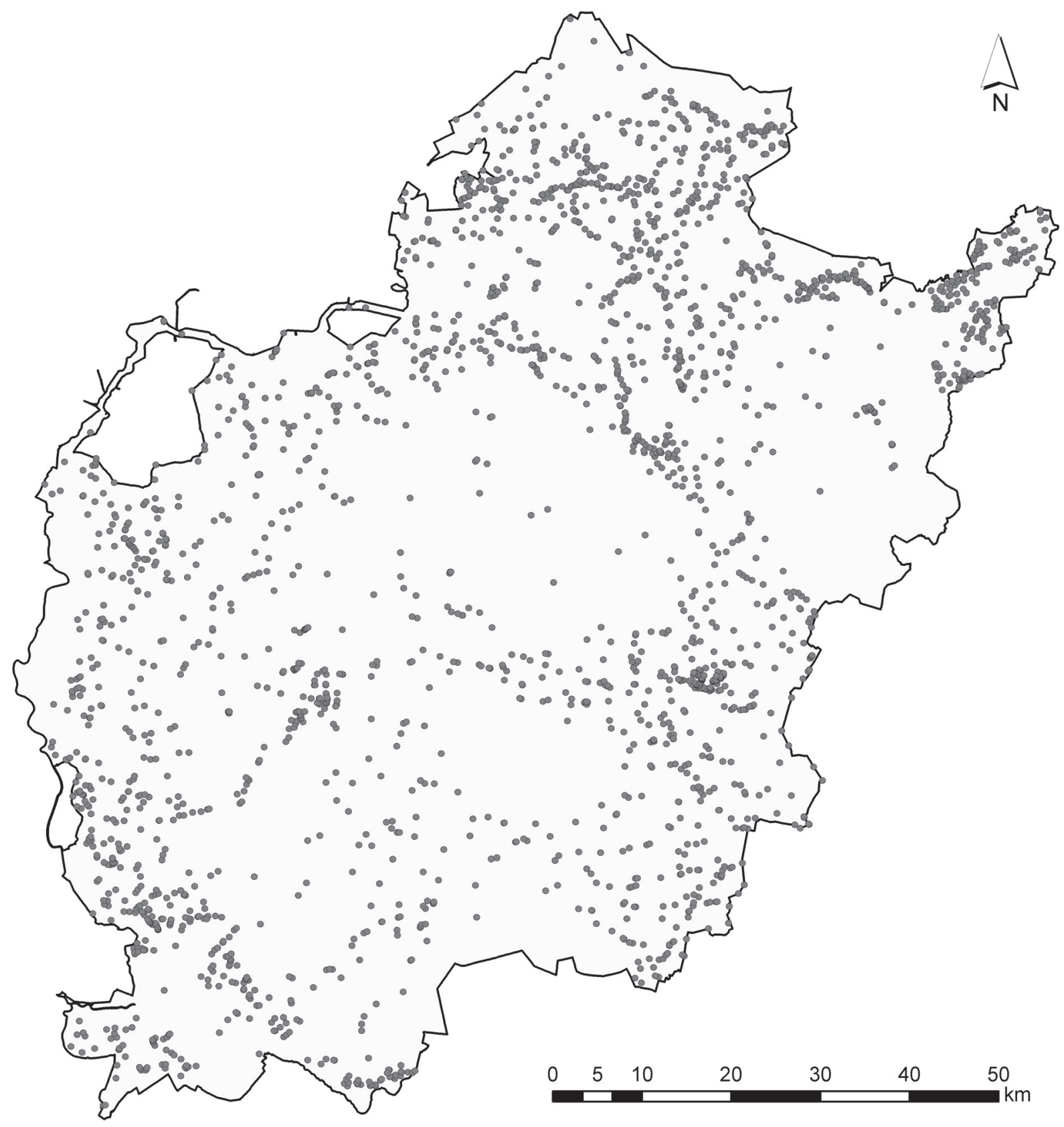

Fig. 9. The registered burial mounds in the study area from our survey (2335 kurgans) (BEDE 2016, 134)

\section{ACKNOWLEDGEMENTS}

Here we would like to say special thank for the help to László Tirják, Péter Bánfi, János Greksza, Péter Czukor, András István Csathó, József Áron Deák, Mária Bodnár and Pál Sümegi, furthermore for the support to the Körös-Maros National Park Directorate (Szarvas) and the scholarship (PD 121126) of the National Research, Development and Innovation Office (Budapest). 


\section{REFERENCES}

BARCZI 2003

BARCZI et al. 2011

BARCZI 2016

BEDE 2008

BEDE 2016

BEDE-CZuKor 2018

BODNÁR 1983

BÖKÖNYI 1979

CSALOG 1954

CSATHÓ 2008

CsizmaZia 1982

CsizmaZia a 1986

DANI-HORVÁTH 2012

DEÁK 2018

DEÁK 2010

DÉTÁR 2012

DomoKos 2018a

DOMOKOS 2018b

DövÉNYI 1986

DöVÉNYI 2010

DöVÉNYI et al. 1977

Duma 1979

DUMA-ECSEDY 1975
= A. BARCZI: Kunhalmok, mint a vegetációtörténet és a talajfejlődés őrei [Mounds like guardians of the history of vegetation and soil development]. In: III. Kárpát-medencei Biológiai Szimpózium. 2003. október 29-31. Eds: K. Penksza, Z. Korsós, I. Papp. Budapest 2003, 5-11.

= A. Barczi-K. PenKsza-K. Joó: Soil-plant associations on kurgans of the Great Hungarian Plain. Agrokémia és Talajtan 60 (2011) 293-304.

= A. BARCZI: Kunhalmok eltemetett talajainak vizsgálata [Examination on buried soils of mounds]. Gödöllö 2016.

= Á. BEDE: Szentes halmai (Mounds of Szentes). Szentesi műhely füzetek 10. Szentes 2008.

= Á. BEDE: Kurgánok a Körös-Maros vidékén... Kunhalmok tájrégészeti és tájökológiai vizsgálata a Tiszántúl középső részén (Kurgans in the Land of the Körös and Maros Rivers... Landscape archaeological and landscape ecological investigations on mounds in the central part of the Tiszántúl region, Hungary). Budapest 2016.

= Á. BEDE-P. CzuKoR: A kétegyházi kurgánmező roncsolt halmainak helyreállítási javaslata (Reconstruction proposal for damaged mounds of the kurgan field near Kétegyháza, Hungary). Crisicum 10 (2018) 7-30.

= B. BoDNÁR: Hódmezővásárhelynek és környékének földrajzi nevei [Toponyms of Hódmezővásárhely and its Vicinity]. Tanulmányok Csongrád megye történetéböl 7. Szeged 1983.

= S. BÖKÖNYI: Copper Age vertebrate fauna from Kétegyháza. In: ECSEDY 1979, 101-118.

= J. CsAlOG: Az alföldi halomkutatás [Research on mounds in the Great Plain]. MúzHír 4 (1954) 82-85.

= A. I. CsATHÓ: Ôsi sztyepprétmaradvány a medgyesegyházi temetőben [Ancient steppe fragment in the cemetery of Medgyesegyháza]. In: A Magyar Biológiai Társaság XXVII. Vándorgyülése, 2008. szeptember 25-26. Eds: Z. Korsós, Gy. Gyenis, K. Penksza. Budapest 2008, 19-25.

= Gy. CsizMAZIA: A kurgánok gerinces állatainak vizsgálata [Examination on vertebrates of the kurgans]. MKCsM 1982 (1982) 209-214.

= Gy. Csizmazia: Mammológiai vizsgálatok a Szabadkígyósi Tájvédelmi Körzetben. I.: A szikes puszta emlősei (Mammologic investigations in the Szabadkígyós Landscape Protection Area. 1.: Mammalians of the salt steppe). Környezet- és Természetvédelmi Évkönyv 6 (1986) 311-331.

= J. DANI-T. HoRVÁTH: Öskori kurgánok a magyar Alföldön. A Gödörsíros (Jamnaja) entitás magyarországi kutatása az elmúlt 30 év során. Áttekintés és revízió [Ancient Kurgans on the Great Hungarian Plain. The research of the Pit Grave (Yamnaya) Entity in the last 30 years in Hungary. Survey and revision]. Budapest 2012.

= B. DEÁK: Természet és történelem. A kurgánok szerepe a sztyeppi vegetáció megőrzésében [Nature and History. Role of the kurgans in the conservation of the steppe vegetation]. Budapest 2018.

= J. Á. DEÁK: Csongrád megye kistájainak élőhelymintázata és tájökológiai szempontú értékelése (Habitat-pattern and landscape ecological evaluation of the microregions of Csongrád county). [Diss. University of Szeged. Manusript.] Szeged 2010.

= L. DÉTÁR: Botanikai vizsgálatok Szarvas környéki kunhalmokon [Botanical investigations on mounds in the vicinity of Szarvas]. In: Válogatott tudományos diákköri munkák 2011-ben. Eds: E. Csengeri, J. Szitó. Agrártörténeti füzetek 33. Békéscsaba-Szarvas-Gyula 2012, 11-49.

$=\mathrm{T}$. DomoKos: Adatok néhány Hódmezővásárhely környéki halmon található gyep csigaegyütteséről (Data to the molluscan associations of some mounds in the environs of Hódmezővásárhely [TransTisza region, Csongrád county]). Crisicum 10 (2018) 107-117.

= T. Domokos: Szórványadatok Mindszent (DS 34, 35, 45) recens malakofaunájához (Mollusca), különös tekintettel néhány halmára (Harangos, Nagy, Gál, Hegyes, Koszorús, Móra, Ludas) (19862015) (Sporadic data on the recent Molluscs of Mindszent Town outskirts [Hungary, Csongrád County], with special reference to some mounds [Harangos, Nagy, Gál, Hegyes, Koszorús, Móra, Ludas], 1986-2015). Crisicum 10 (2018) 119-141.

= Z. DöVÉnYI: A szabadkígyósi puszta mikroklimatikus viszonyai (The micro-climatic conditions of the Szabadkígyós steppe). Környezet- és Természetvédelmi Évkönyv 6 (1986) 81-97.

= Z. DövÉNYI (ed.): Magyarország kistájainak katasztere [Cadastre of the Small Landscape Regions in Hungary]. Budapest 2010. - Second, rev., extended ed.

= Z. DövÉNYI-L. Mosolygó-J. RAKOnCZAI-J. TóTH: Természeti és antropogén folyamatok földrajzi vizsgálata a kígyósi puszta területén (Geographical survey of natural anthropogen processes on the puszta Kígyós). Békés Megyei Természetvédelmi Évkönyv 2 (1977) 43-72, 161-163, 174-176.

= Gy. DuMA: Chemical analysis of the ochre-clods in some pit-graves. In: ECSEDY 1979, 99.

= Gy. DuMA-I. EcSEDY: Die "Ockerklumpen" der Grubengrab-kultur - Jamnaja-kultur. MittArchInst 4/1973 (1975) 129-133. 
ECSEDY 1979

ECSEDY-VIRÁGH 1975

ELTE 2001

HERCZEG 2005

HERCZEG 2015

HerCZEG et al. 2006a

Herczeg et al. 2006b

HeRCZEG et al. 2009

JAKAB-DELI 2012

JАКАВ-ТóTH 2003

KÁDÁR 1941

KAPOCSI et al. 1998

KERTÉSZ 2000

KISPÁL 2002

KISPÁL 2004

KISS 1988

KovÁCS-MoLnÁR 1986

KozMA 1910

KRAUSZ et al. 2000

KULCSÁR 1998

Kunhalom-program 2002

MARCSIK 1979

MedovarsZKY 2010

MERKL et al. 2014
= I. ECSEDY: The People of the Pit-Grave Kurgans in Eastern Hungary. FontArchHung. Budapest 1979, $1-85$.

= I. ECSEDY-D. VIRÁGH: Vorbericht über eine Untersuchung nach der Verbreitung der Kurgane in Ostungarn. MittArchInst 4/1973 (1975) 31-35.

= Kunhalom és földvár kataszter [Cadastre of Mounds and Earthworks]. Manuscript. Budapest 2001.

= E. HERCZEG: Botanikai vizsgálatok kunhalmok dél-tiszántúli löszgyepein (Botanical investigation of loess grass vegetation of the southern part of the Tiszántúl kurgans [Hungary]). Kanitzia 13 (2005) 45-54.

= E. HerCZEG: Dél-tiszántúli gyepterületek botanikai feltárása és hasznosítási lehetőségei (Botanical Exploration and Potential Utilization of Grasslands at South-Tiszántúl). [Diss. Szent István University. Manuscript.] Gödöllö 2015.

= E. HercZeG-A. BArCZi-K. Penksza: Examinations on plants soil and in grasslands of South-east Hungary (Floristical summary and the vegetation of Sáp kurgan) (Dél-tiszántúli kunhalmok botanikai és talajtani vizsgálatai. Florisztikai összefoglaló, Sáp-halom vegetációja). Tájökológiai Lapok 4 (2006) 95-102.

= E. HerczeG-Sz. Szentes-K. PenKsza: Kunhalmok aspektusai [Aspects of mounds]. In: A Magyar Biológiai Társaság XXVI. Vándorgyülése, 2006. november 9-10. Eds: Z. Korsós, Gy. Gyenis, K. Penksza. Budapest 2006, 239-244.

= E. HerczeG-T. Szerdahelyi-G. Gubcsó: Botanikai vizsgálatok Dél-Tiszántúli gyepekben (Botanical investigations in grasslands of South-East Hungary). Crisicum 5 (2009) 29-49.

= G. JAKAB-T. DELI: A Dél-Tiszántúl természetföldrajzi viszonyai [Natural conditions of the South Tiszántúl region]. In: A Körös-Maros Nemzeti Park növényvilága. Ed.: G. Jakab. A Körös-Maros Nemzeti Park természeti értékei 1. Szarvas 2012, 26-33.

= G. JAKAB-T. TóTH: Adatok a Dél-Tiszántúl flórájának ismeretéhez (New data to the flora of the South-Tiszántúl [SE-Hungary]). Kitaibelia 8 (2003) 89-98.

= L. KÁDÁR: A magyar nép tájszemlélete és Magyarország tájnevei [Landscape Approach of the Hungarians and Landscape Toponyms of Hungary]. A magyar táj- és népismeret könyvtára 3. Budapest 1941.

= J. KAPOCSI-E. DOMÁN-I. BíRÓ-B. ForGÁCH-T. TóTH: Florisztikai adatok a Körös-Maros Nemzeti Park müködési területéről (Some floristical data from the operation area of the Körös-Maros National Park). Crisicum 1 (1998) 75-83.

= É. KERTÉsz: Adatok a Dél-Tiszántúl flórájához (Data concerning the flora of South-Tiszántúl). BMMK 21 (2000) 5-48.

= Z. KISPÁL: A mindszenti és a szentesi kunhalmok természetvédelmi-botanikai vizsgálata [Nature Conservation and Botanical Investigation on the Mounds in Mindszent and Szentes]. [Thesis, Szent István University. Manuscript.] Budapest 2002

= Z. Kispál: A mindszenti és szentesi kunhalmok természetvédelmi-botanikai vizsgálata [Nature conservation and botanical investigation on the mounds in Mindszent and Szentes]. In: A kunhalmokról - más szemmel (Kurgans). Ed.: A. Tóth. Kisújszállás-Debrecen 2004, 71-79.

= L. KISs: Földrajzi nevek etimológiai szótára [Etymological Dictionary of toponyms]. I-II. Budapest 1988. Second, impr., extended ed.

= A. KovÁCs-Z. MolNÁR: A Szabadkígyósi Tájvédelmi Körzet fontosabb növénytársulásai [Important plant associations of the Szabadkígyós Landscape Protection Area]. Környezet- és Természetvédelmi Évkönyv 6 (1986) 165-199.

= B. KozmA: A kunhalmok elhelyezkedése az Alföldön [The locality of the mounds in the Great Plain]. FrK 38 (1910) 437-443.

= K. KraUSZ-J. PÁPAI-L. KÖRMÖCZI-A. HorvÁtH: Structure of Orthoptera assemblages in step-like habitat islands and neighbouring grasslands. Articulata - Zeitschrift der Deutsche Gesellschaft für Orthopterologie e.V. 15 (2000) 167-177.

= V. KULCSÁR: A Kárpát-medencei szarmaták temetkezési szokásai (The burial rite of the Sarmatians of the Carpathian Basin). MúzFüz Aszód 49. Aszód 1998.

= Országos kunhalom-kataszter és adatbázis [National Kunhalom Cadastre and Database]. Manuscript (database). Budapest-Kisújszállás 2002.

= A. MARCSIK: The anthropological material of the Pit-grave kurgans in Hungary. In: ECSEDY 1979, 87-98.

= M. Medovarszky: Az Elek-Kétegyháza-Szabadkígyós térségében levő kunhalmok természetvédelmi értéke [Nature value of the mounds in region of Elek, Kétegyháza and Szabadkígyós]. [Thesis, University of Debrecen. Manuscript.] Debrecen 2010.

= O. MERKL-V. KÖDÖBÖCZ-T. DELI-T. DANYIK: Bogárfaunisztikai adatok a Dél-Tiszántúlról (Coleoptera) (Faunistic data to the beetles from the south-eastern Great Hungarian Plain [Coleoptera]). Crisicum 8 (2014) 99-152. 
MOLNÁR 1992

MRT 6

MRT 8

MRT 10

MRT IV/4

NAGY 1819

NAGY 2012

PÁLÓCZI HoRvÁTH 1996

PenKSZA-KAPOCSI 1998

PenKsZa et al. 2005

Perecsenyi Nagy 1819

Pető-BARCZi 2011

RÁKÓCZI 2016

RAKONCZAI 1986

RóZsA 1979

RóZSA 2002

SZABÓ 1859

SZEGHALMI 1912

SZEGHALMI 1936

SZELEKOVSZKY 1999

TORMA 2008

TORMA 2015

TóтH-Tóтн 2011

Tо́тн 2003

VIRÁGH 1979
= Zs. MoLNÁR: A Pitvarosi puszták növénytakarója, különös tekintettel a löszpusztagyepekre (Vegetation of "Pitvarosi-puszták" with special respect on loess hills). Botanikai Közlemények 79 (1992) 19-27.

= I. ECSEDY-L. KovÁCS-B. MARÁZ-I. TORMA: Békés megye régészeti topográfiája. IV/1.: A szeghalmi járás. MRT 6. Budapest 1982.

= D. JANKovich B.-J. MAKKAY-B. M. SzŐKE: Békés megye régészeti topográfiája. IV/2.: A szarvasi járás. MRT 8. A Budapest 1989.

= D. Jankovich B.-P. Medgyesi-E. Nikolin-I. Szatmári-I. Torma: Békés megye régészeti topográfiája. IV/3.: Békés és Békéscsaba környéke. MRT 10. Budapest 1998.

= I. SzATMÁRI (ed.): Békés megye régészeti topográfiája. IV/4.: A volt gyulai és sarkadi járás. Manuscript, in preparation.

= F. NAGY: Hód Mező Vásárhely Várossa’ rövid rajzolatja [The short sketch of Hódmezővásárhely town]. TGy 3/2 (1819) 34-57. - also edited in: Magyar tájak néprajzi felfedezői. A magyar néprajz klasszikusai. Ed.: A. Paládi Kovács. Budapest 1985, 221-232.

= I. NAGY: A kétegyházi Török-halom rekonstrukciója (Restoration of Török-halom kurgan near Kétegyháza). BMMK 36 (2012) 87-108.

= A. PÁlóczi Horváth: Nomád népek a kelet-európai steppén [Nomad people in the steppe of East Europe]. In: Zúduló sasok. Új honfoglalók - besenyők, kunok, jászok - a középkori Alföldön és a Mezőföldön. Ed.: P. Havassy. Gyulai katalógusok 2. Gyula 1996, 7-36.

= K. PenksZA-J. Kapocsi: A Maros-völgy edényes növényei. I. (Vascular Plants of Maros-valley. I.). Crisicum 1 (1998) 35-74.

= K. PenKsZA-M. VonA-E. HerCZEG: Eltérö gazdálkodás során fenntartott természetes gyepek botanikai és talajtani vizsgálata tiszántúli kunhalmokon (Botanical and pedological investigations on natural grasslands under various management systems on ancient burial mounds in the Tiszántúl region of Eastern Hungary). Növénytermelés 54 (2005) 181-195.

= L. PerecsenYi NAGY: Arad vármegye régiségei közé számlálható halmokról [Mounds like ancent objects in Arad County]. TGy 3/2 (1819) 80-82.

= Á. PetŐ-A. BARCZI (eds): Kurgan Studies. An Environmental and Archaeological Multiproxy Study of Burial Mounds in the Eurasian Steppe Zone. BAR IntSer 2238. Oxford 2011.

= A. RÁKÓCZI: Kunhalmok és emberek az évezredek sodrában. A közös agrárpolitika tájvédelmi elöírásainak hatásai a Békés megyei kunhalmok állapotára [Mounds and People in the Millenniums. Effects of common agricultural policy on landscape protection of the mounds in Békés County]. Budapest 2016.

= J. RAKONCZAI: A szabadkígyósi puszta földtani viszonyai és geomorfológiája (The geological conditions and the geomorphology of the Szabadkígyós steppe). Környezet- és Természetvédelmi Évkönyv 6 (1986) 7-18.

= G. RózsA: Halmok. Csongrád megye. [Manuscript.] Szeged 1979. Archaeological Repository of Móra Ferenc Museum (Szeged) 851-82/1-2, 1300-1301-89.

= G. RózSA: Hódmezővásárhely halmai és a jelentősebb laponyagok [Mounds and important "laponyags” of Hódmezővásárhely]. In: Dömötör János emlékkönyv. Tanulmányok a 80 éves Dömötör János tiszteletére. Ed.: V. Nagy. Múzeumi mühely 1. Hódmezővásárhely 2002, 36-67.

= J. SzABó: A békés-csanádi halmok földtani tekintetben [The mounds of Békés and Csanád regions in geological aspects]. Budapesti Szemle 6 (1859) 175-187.

= Gy. Szeghalmi: A szeghalomvidéki (Békés megye) halmokról [About the mounds in the vicinity of Szeghalom (Békés County)]. ArchÉrt 32 (1912) 276-281.

= Gy. Szeghalmi: Szeghalmi járás története [History of Szeghalom District]. In: Békés vármegye. Ed.: Gy. Márkus. Budapest 1936, 349-383.

= L. SzeleKovszKY: Békés megye kunhalmai [Mounds of Békés County]. Békéscsaba 1999.

= I. ToRmA: Laponyag (Tiszántúli halmok sajátos elnevezése) (Laponyag. A peculiar name of hillocks in the Trans-Tiszanian region). In: Név és valóság. A VI. Magyar Névtudományi Konferencia előadásai. Eds: A. Bölcskei, I. N. Császi. A Károli Gáspár Református Egyetem Magyar Nyelvtudományi Tanszékének kiadványai 1. Budapest 2008, 272-277, 676.

= I. TORMA: Régészeti vonatkozású helynevek a történelmi Magyarország területén (Locality names with archaeological implications in the territory of historical Hungary). Archeometriai Mühely 12 (2015) 67-73.

= Cs. То́тH-A. То́тн: The complex condition assessment survey of kurgans in Hungary. In: PetőBARCZI 2011, 9-17.

= T. То́тн: Újabb adatok a Dél-Tiszántúl flórájának ismeretéhez [New data for the knowledge of the flora in the South Tiszántúl region]. A Puszta 20 (2003) 135-169.

= D. VIRÁGH: Cartographical data of the kurgans in the Tisza Region. In: ECSEDY 1979, 119-148. 
VONA-PENKSZA 2004

K. ZOFFMANN 1978

K. ZOFFMANN 1984
= M. VonA-K. PEnKsZA: A szentesi Kántor-halom vegetációjának változása és ennek összefüggése a talaj vízháztartásával (Change of the vegetation on the Kántor kurgan and its relation with the soil water regime). Tájökológiai Lapok 2 (2004) 341-348.

= Zs. K. ZofFMAnN: Das anthropologische Material der Ockergräber-Bestattung von SzentesBesenyőhalom. MFMÉ 1976-1977/1 (1978) 39-40.

= Zs. K. ZoFFMANN: Das anthropologische Material der Kurganbestattung von Derekegyház-Ibolyásdomb (Kurgántemetkezés embertani anyaga Derekegyház-Ibolyásdombról). MFMÉ 1980-1981/1 (1984) 99-109.

Open Access. This is an open-access article distributed under the terms of the Creative Commons Attribution 4.0 International License (https:// creativecommons.org/licenses/by/4.0), which permits unrestricted use, distribution, and reproduction in any medium, provided the original author and source are credited, a link to the CC License is provided, and changes - if any - are indicated. (SID_1)

Acta Archaeologica Academiae Scientiarum Hungaricae 70, 2019 